\title{
REGIONAL AIRPORTS AND THE ACCESSIBILITY OF MOUNTAIN AREAS: NETWORKS, IMPORTANCE AND CONTRIBUTION TO DEVELOPMENT
}

\author{
X. BERNIER \\ Laboratoire EDYTEM, CNRS, Université de Savoie, France.
}

\begin{abstract}
This paper looks at the role and importance of regional airports in mountain areas. The question of accessibility is examined at different scales, from regional airports serving mountain areas to high-altitude aerodromes (altiports) and airstrips (altisurfaces) in mountain resorts. The ways in which air transport is integrated into intermodal transport systems serving tourist areas, most notably mountain resorts, are also investigated. Given the highly seasonal and specific nature of their use, many airports serving mountain areas are faced with problems of over-sizing or seasonal congestion. Issues such as the socio-economic and environmental integration of regional airports are also extremely important for mountain areas. Altiports and altisurfaces can contribute substantially to the tourism development of mountain regions by improving accessibility for visitors and through leisure aviation. Consequently, regional airports have a substantial impact on an area's image, whether they are viewed positively, as an aid to development, or negatively, as harmful to the environment. The present analysis was based on several case studies that highlight different aspects of regional air transport in mountain areas. The specificities of regional airport development in the Alps, and particularly in France, are illustrated by the story of Air Alpes. Attention is also focused on the links between the United Kingdom and Chambéry and Grenoble airports, which are dominated by low-cost airlines. Looking at the larger picture, examples of mountain-periphery and extra-mountain airports in France, Switzerland and Nepal are examined in order to investigate the formation of networks, the importance of regional airports and their contribution to regional development.

Keywords: accessibility, Alps, altiports, Himalaya, mountain, regional airports, transport networks, tourism.
\end{abstract}

\section{INTRODUCTION}

Giblin's [1] work on regional airports highlights the exceptional density of airports in countries such as the United States and France. For example, France has 1.02 airports per million inhabitants (based on airports with a traffic flow of more than 10,000 passengers per year). Even if the difference with its European neighbours is less substantial when airport density is calculated as a function of the size of the country, its large volume of tourist traffic tends to make France a special case. Traffic-flow statistics for 2008 [2] show that France's mountain and mountain-periphery airports have performed particularly well. These airports include Chambéry $(270,632$ passengers) and Grenoble $(469,777)$ in the Alps, and Tarbes $(678,897)$ in the Pyrenees (Table 1). Having grown rapidly since 2002, these airports are characterised by very high percentages of international traffic $(83.5 \%$ of recorded traffic in 2008 for Tarbes, $98.5 \%$ for Chambéry and $99.5 \%$ for Grenoble). At a time of rapid restructuring within the air-transport sector, and although the implications of the current financial crisis are difficult to discern, these airports have benefited from the development of links with northern Europe, in particular with Scandinavia and Great Britain. Most of this growth can be attributed to the development of low-cost services (76,210 passengers, an increase of 78.7\% since 2004 for Chambéry) and of business aviation, even if the neighbouring international airports of Geneva-Cointrin (Switzerland) and Lyon-Saint Exupéry (France) are becoming increasingly competitive in this latter market. One of the cornerstones for these ongoing processes is the liberalisation of air transport [3, 4], which began in the early 2000s. 
Table 1: Statistics for France's three regional mountain airports.

\begin{tabular}{|c|c|c|c|c|c|c|c|c|}
\hline & $\begin{array}{l}\text { Passengers } \\
2008\end{array}$ & $\begin{array}{c}2004-200 \\
(\%)\end{array}$ & $\begin{array}{c}\% \text { of } \\
\text { international } \\
\text { traffic }\end{array}$ & $\begin{array}{c}\text { Incl. } \\
\text { low-cost } \\
\text { services }\end{array}$ & Main airlines & $\begin{array}{l}\text { Area } \\
\text { (ha) }\end{array}$ & $\begin{array}{l}\text { Run } \\
\text { away } \\
\text { (m) }\end{array}$ & $\begin{array}{c}\text { Car } \\
\text { parks } \\
(\mathrm{m}+2)\end{array}$ \\
\hline Chambéry & 270,632 & 10.6 & 98.5 & 76,210 & $\begin{array}{l}\text { Jet2/Flybe/ } \\
\text { Snowjet }\end{array}$ & 100 & 2,020 & 35,000 \\
\hline Grenoble & 469,777 & 23.2 & 99.5 & 242,477 & $\begin{array}{l}\text { Easyjet/Ryanair/ } \\
\text { Transavia/Wizz air }\end{array}$ & 200 & 3,050 & 45,000 \\
\hline Tarbes & 678,897 & 13.4 & 83.5 & & Air France & 196 & 3,000 & 62,000 \\
\hline
\end{tabular}

Source: UDF/2008.

The development of mountain airports must be considered in terms of access to mountain areas, particularly tourist areas. Hence, the present article examines the accessibility of mountain areas through the prism of regional airports. It begins by showing how the development of airlines such as Air Alpes contributed to the formation of a network of airports. These airports formed the foundation for a 'primary' air-transport network. The development and evolution of specialist airfields, such as 'altiports' (a term coined in 1962 following the first landing on a rough airstrip at Meribel in the French Alps), is one of the keys for understanding the current situation. However, accessibility has often become synonymous with intermodality, with different types of intermodal strategy for connecting mountain areas to regional airports being possible. The article concludes by presenting a typology of regional airports based on how they are integrated into evolving mountain and mountain-periphery transport systems.

\section{ACCUMULATIVE FORMATION OF A NETWORK OF SERVICES AND THE NODAL-AXIAL INTERACTIONS AT THE ORIGIN OF A 'PRIMARY' AIR-TRANSPORT NETWORK}

Transport networks in mountain areas were not designed as networks from the outset. The networks we see today were formed by the accumulation of individual services set up by the pioneers of mountain aviation. The result was a transportation network that can be considered 'primary'.

\subsection{Specific infrastructure, technical and legal frameworks}

The specific characteristics of the mountain environment led Debarbieux [5] and Sacareau [6] to re-examine and redefine the scientific paradigms used to define the notion of 'mountain area'. Because mountains impose a certain number of constraints on air traffic, and because of the distinctive characteristics of mountain aerodromes and traffic flows, the infrastructure, technical and legal frameworks surrounding mountain airports are often highly specific. Regional airports capable of accepting a wide range of aircraft require large areas of land. For example, Tarbes airport covers 196 ha, which includes 62,000 $\mathrm{m}^{2}$ of car parks and a 3,000-m runway. Grenoble and Chambéry airports both cover $200 \mathrm{ha}$, and have $45,000 \mathrm{~m}^{2}$ and 35,000 $\mathrm{m}^{2}$ of car parks and 3,000-m and 2,000-m runways, respectively. Suitable sites are often difficult to find because the flat expanses of land airports needs tend to be coveted for other uses and areas surrounding centres of population are often already built up. Sandwiched between Lake Bourget and the mountains, Chambery airport undoubtedly feels most strongly the constraints imposed by mountain topography. In fact, pilots landing at 
Chambéry have to undergo specific training and obtain a special qualification. Most regional airports are nevertheless located at low altitude. Airports at higher altitudes are subject to local conditions. In its Aeronautical Information Publication, France's Civil Aviation Authority (Direction Générale de l'Aviation Civile) defines altiports as aerodromes with special characteristics built in mountain areas for the purposes of air transport. They are approved for restricted uses and pilots and aircraft using these aerodromes must meet the conditions stipulated by the head of the district. France has an especially large number of this type of airfield (Mégève in Haute-Savoie, Courchevel and Méribel in Savoie, Alpe d'Huez in Isère, Corlier in the Ain, La Motte-Chalançon in the Drôme and Peyresourde in the Hautes-Pyrénées). Most have tarmac runways and some have a control tower. Altisurfaces (including 'glacier' altisurfaces) are areas in the mountains that can be used by certain types of aircraft for air travel, transport on demand or non-commercial air operations. They are certified under prefectoral by-laws and restricted to pilots and aircraft that meet certain conditions. In both cases, pilots making wheeled landings must have a 'mountain' qualification, and pilots making ski landings must have a ski qualification (snow extension). Some altiports also require pilots to have a 'site authorisation'. It should be noted that France is the only country with specific legislation for altiports and altisurfaces. Despite the specific topography-related conditions associated with airfields in the mountains (mountain wind systems, local turbulence/'rabattants', foehn winds, venturi effect), pilots do not need any special qualifications when the departure and arrival points are 'classic' aerodromes. The lack of flat ground has been turned into an advantage, as altiports and altisurfaces use the slope to assist take-offs and landings. Another factor that may be more limiting in some mountain areas is flight restrictions associated with national parks: by law, aircraft cannot fly low over national parks, regional parks and nature reserves (minimum altitude of $1,000 \mathrm{~m}$ above ground for national parks and $300 \mathrm{~m}$ above the ground for regional parks and nature reserves). Despite these difficulties, most altiports and altisurfaces (C and D) are linked to regional airports (B). Figure 1 provides a summary model of the processes at work. The resulting network constitutes a more or less whole, even if operations are very seasonal and reliant on tourism. A small number of actors have been determinant in the development of this network.

\subsection{A cumulative process that is closely linked to the story of certain airlines}

In this process of network formation by accumulation, which truly began in the early 1960s, Air Alpes is a key company for understanding the improved accessibility of mountain areas and, more generally, the recent history of regional aviation in Western Europe. Formed in 1961 by two French pilots, Robert Merloz and Michel Ziegler, Air Alpes was the first airline to be set up specifically to provide regular services to ski resorts (which led in 1962 to the building of the world's first altiports at Courchevel - where Air Alpes had its head office - and at Méribel) and to offer new services within resorts, such as landing skiers on glaciers. The first phase was the creation of winter services (Lyon to Courchevel and Méribel and Geneva to Courchevel and Méribel), connections with other altiports (such as La Plagne, Val d'Isère, Alpe d'Huez, Avoriaz and Tignes), the first inter-resort services, and the first summer services to Corsica (Ajaccio, Propriano, Calvi). In 1967, 10,590 passengers were carried using aircraft such as the famous Pilatus Turbo Porter. The second period, starting in 1968, was the golden age of regional aviation. Air Alpes contributed enthusiastically to this development, alongside other airlines such as Rousseau Aviation, TAT (Touraine Air Transport), Air Paris and Europe Aéro Service. Almost 50 airlines operated a total of 100 regular or seasonal services and carried more than 500,000 passengers. Aircraft plying the Chambéry (where Air Alpes now had its head office)-Grenoble-Nice-Ajaccio route were even fitted with skis in order to land at Courchevel altiport! This was the era of flights from Paris-Le Bourget to Chambéry (in 115 min and, 
(a)

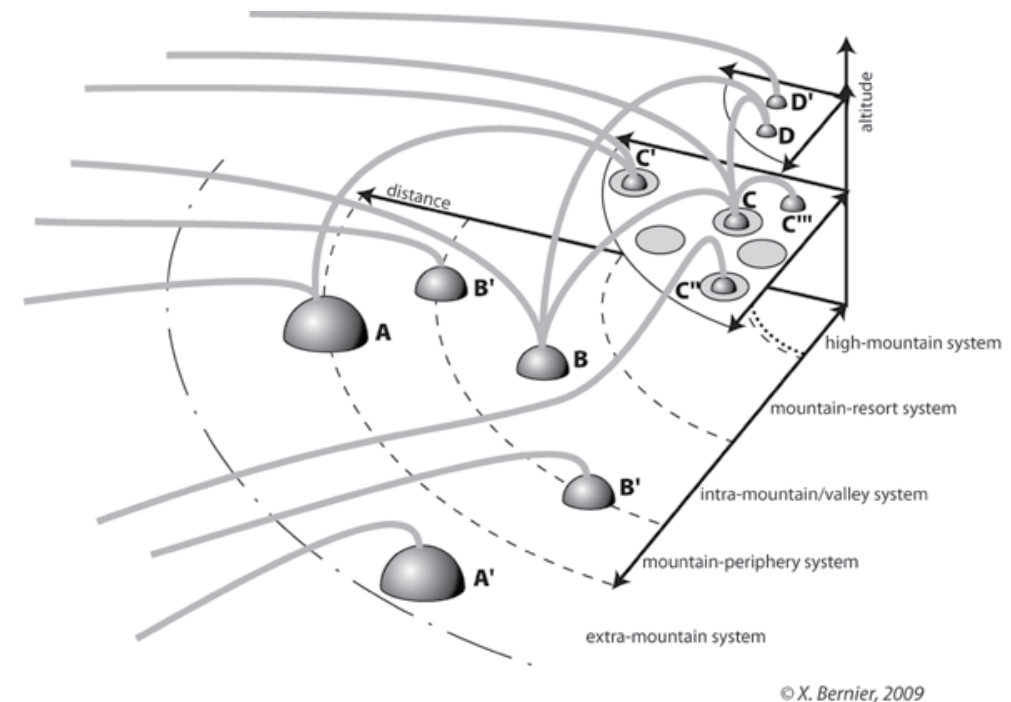

(b)
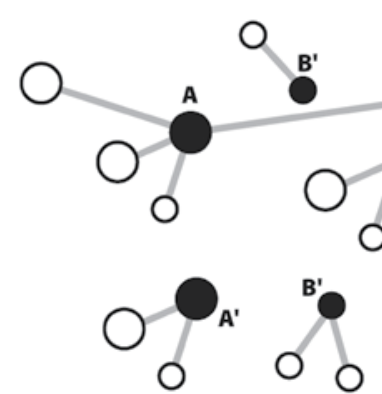

0
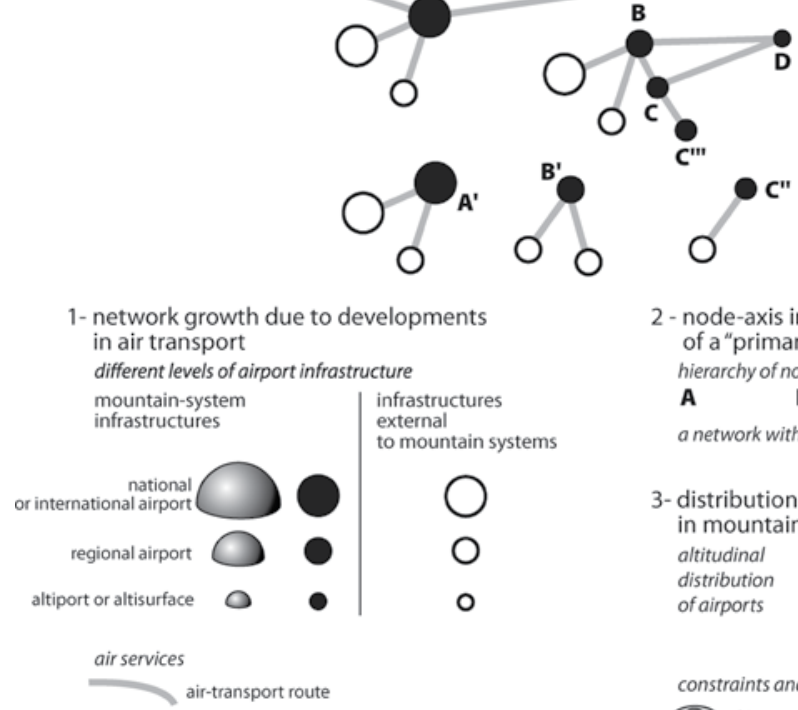

2 - node-axis interactions at the origin of a "primary" network

hierarchy of nodes in the transport network

A

a network with low connectivity and low connectedness see Fig. $1 \mathrm{~b}$

3- distribution of airports and related activities in mountain areas

altitudinal distribution
of airports

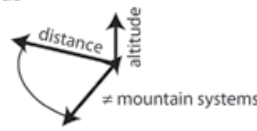

constraints and opportunities related to the mountain setting (C) ski resort served $\bigcirc$ not served

$\because, \ldots . \quad$ boundary of protected area, traffic $+/-$ constraint

Figure 1: Formation of networks by accumulation.

most importantly, it was a direct service), Geneva and Lyon to Courchevel, Grenoble to Alpe d'Huez, and Nice to Courchevel. It also saw links being made with other airlines, such as Switzerland's ATA (Air Tourisme Alpin) and the formation, largely due to the efforts of Michel Ziegler of ATAR (Association of Air Transporters, which brought together Air Alpes, Air Alsace, Air Aquitaine, Air Languedoc, Pyrénair, Air Rouergue, Air Antilles, Air Martinique and Guyane Air Transport). The airports of Grenoble-St. Geoirs and Lyon-Bron (where Air Inter was based) became the first 'hubs' 
of regional aviation. At the same time, Switzerland's Geneva-Cointrin Airport began to occupy a strategic position in the network. This period also saw the peak of Air Alpes' business with the airline operating almost 50 services in 1973 (using larger Corvette and Fokker aircraft) and introducing new direct services from Paris to Megève (1975) and Alpe d'Huez (1976).

However, the decline was already on the horizon. The TAG group became the main shareholder in Air Alpes (1977), which moved to Paris-Orly. This was followed by agreements with Air Inter, and then with TAT, who took a 75\% interest in Air Alpes in 1981. It was the end of an era that had made a great contribution to the development of regional aviation in France. As is frequently the case, this decline was due to a combination of factors, not least of which was the oil crises of 1973 and 1979. However, there were also technical difficulties that prevented the change from Visual Fly Rule (VFR) navigation to Instrument Fly Rule (IFR) navigation in mountain areas, which are subject to highly variable and unpredictable atmospheric conditions. Competition with new operators was another determining factor, in particular due to the introduction of helicopters at the end of the 1970s, which offered the same made-to-measure, air-taxi type services. There was also increased competition from road transport (dual-carriageway or motorway links, such as the Autoroute Blanche between Geneva and Chamonix) and soon from TGV high-speed rail services. Increasing regulation provided a further obstacle, with the creation of the first national parks (Vanoise National Park set up in 1963) and, in 1980, the ban on landing skiers on glaciers. Although inter-resort services and tourist flights continued, a page seemed to have been turned.

\subsection{Outside France: a few significant examples}

Air Alpes also contributed to the development of regional aviation in other mountain areas, especially in Nepal, where the company invested in commercial mountain aviation. The press coverage given to Air Alpes' transport network in the Alps led pilots from the Royal Nepal Airline Corporation (RNAC) coming to the Alps for the 1973 season, in order to observe operations and to learn to land on and take off from mountainside airstrips at Courchevel's altiport. This was followed by a visit to Nepal by pilots from Air Alpes to continue the Nepalese pilots' training and to advise RNAC on the building of aerodromes with short and steeply inclined runways. Some of these altiports, including Lukla (now called Tenzing-Hilary Airport) on the route to Everest, have been successful because they have daily flights to Kathmandu and because they are located in tourist areas. In the air-transport network, other regional airports, such as Pokhara, have emerged for similar reasons.

Outside France and Nepal, only Spain (Ager in Catalonia), Italy (Chamois Valtournanche in the Aosta Valley), Switzerland (Croix de Cœur Verbier in the Valais) and, more recently, Poland (Zar in the Carpathians) have built altiports, most of which are linked to regional airports. Once again, tourism is essential to maintaining services.

The strategies behind these regional services are relatively complex in all these cases.

\section{INTERMODALITY AND ACCESS: THE WEIGHT OF THE DIFFERENT ACTORS IN CURRENT INTERMODAL STRATEGIES}

3.1 Speed or multiple destinations: an impossible compromise?

Spatial analysis $[7,8]$ provides an important tool for exploring these ongoing processes. The graph method $[9,10]$ can thus be used to reveal the priorities of these networks. The 'connectedness' of a network indicates whether or not it is possible to go from one node to any other node. A network has 
high connectedness if it is possible to go from any one node to all the other nodes, either by a direct arc, or via other nodes. By contrast, the 'connectivity' of a network is a measure of the number of different pathways between nodes. The higher the connectivity index the greater the number of pathways from one node to another. Figure 1 provides a key for deciphering 'primary' air-transport networks, as it describes situations produced when networks form by accumulation. Although a graph may consist of pairs of connected components (for example, A-C' or B-C-C'"'-D), the overall graph may still have a low level of connectedness. Of course, most aerodromes, whatever system they belong to (high-altitude, intra-mountain, mountain-periphery, etc), want to be linked to the network, and regional airports do everything they can to increase the number of destinations they serve. However, with a few exceptions, this generally results in a large number of routes that do not necessarily form a coherent network. Thus, national and international airports (A) provide direct services to regional airports (B) and, sometimes to high-altitude aerodromes ( $\mathrm{C}$ or $\mathrm{D}$ ). Figure $2 \mathrm{~b}$ shows the different ways in which the accessibility of mountain areas can be organised in relation to regional airports. Combined with Figs 1 and 2a, Fig. 2b can be used to investigate the evolving ways in which transport networks are formed.

Transport operators may favour different strategies depending on time of the year, day of the week, the target clientele or profitability, etc. For services to the Alps, the priority of low-cost airlines in winter is the speed (more direct flights to the Alps). In summer, the same airlines favour other airports. Another strategy is to serve a maximum number of places, even if this increases journey times and involves changing to a different mode of transport.

Air Alps has modified its strategy several times depending on market conditions. In the first half of the 1970s, when Air Alpes was at its peak, there were several services linking type A airports (such as Paris-Le Bourget, Paris-Orly or Geneva-Cointrin) with type B airports (such as Lyon-Bron, Chambéry or Grenoble-St. Geoirs) or directly with type C or D aerodromes (such as Alpe d'Huez, Megève or Courchevel). Courchevel's altiport managed to maintain a regular commercial service after the end of the Air Alpes era. Initially, it was run by TAT, using aircraft with wheeled undercarriages that could carry 18 , and then 40 passengers. It was later taken over by the Austrian airline Tyrolean Airways, operating under the TAT flag, which provided return flights from Paris-Orly to Courchevel at weekends, and later introduced charter flights from Graz-Innsbruck to Courchevel. Savoie Airlines, and then Alpe Azur picked up the reins during the winters of 1998-1999 and 19992000, after which regular commercial mountain aviation ceased definitively in France. Commercial helicopter-taxi flights and 'on-demand' flights then began (see below) in order to provide direct connections with sometimes-distant airports. Tourism, particularly ski-resort winter tourism is essential to the continued operation of this type of service. The modernisation of Courchevel altiport has also played an important role. In other areas, these services are based on more traditional airports. For example, the Swiss airports of Sion and Lugano form arrival points for mostly tourist air services. This is even more clearly the case for Samedan, Europe's highest aerodrome (1,707 m), which provides an almost direct gateway to the upmarket resort of St. Moritz. Saanen, which provides direct access to Gstaad, is another example.

However, new challenges for intermodal strategies are now emerging [11].

\subsection{The example of the northern French Alps}

The northern French Alps once again provides an edifying case study that can be more clearly understood with reference to Fig. 2. As indicated above, the current air-transport network was created over a long period of time. Within this network, the airports of Lyon-Bron, Grenoble-St. Geoirs and Chambéry played the role of small regional hubs [12]. Since 2004, Grenoble-St. Geoirs and Chambéry 
(a)

(b)
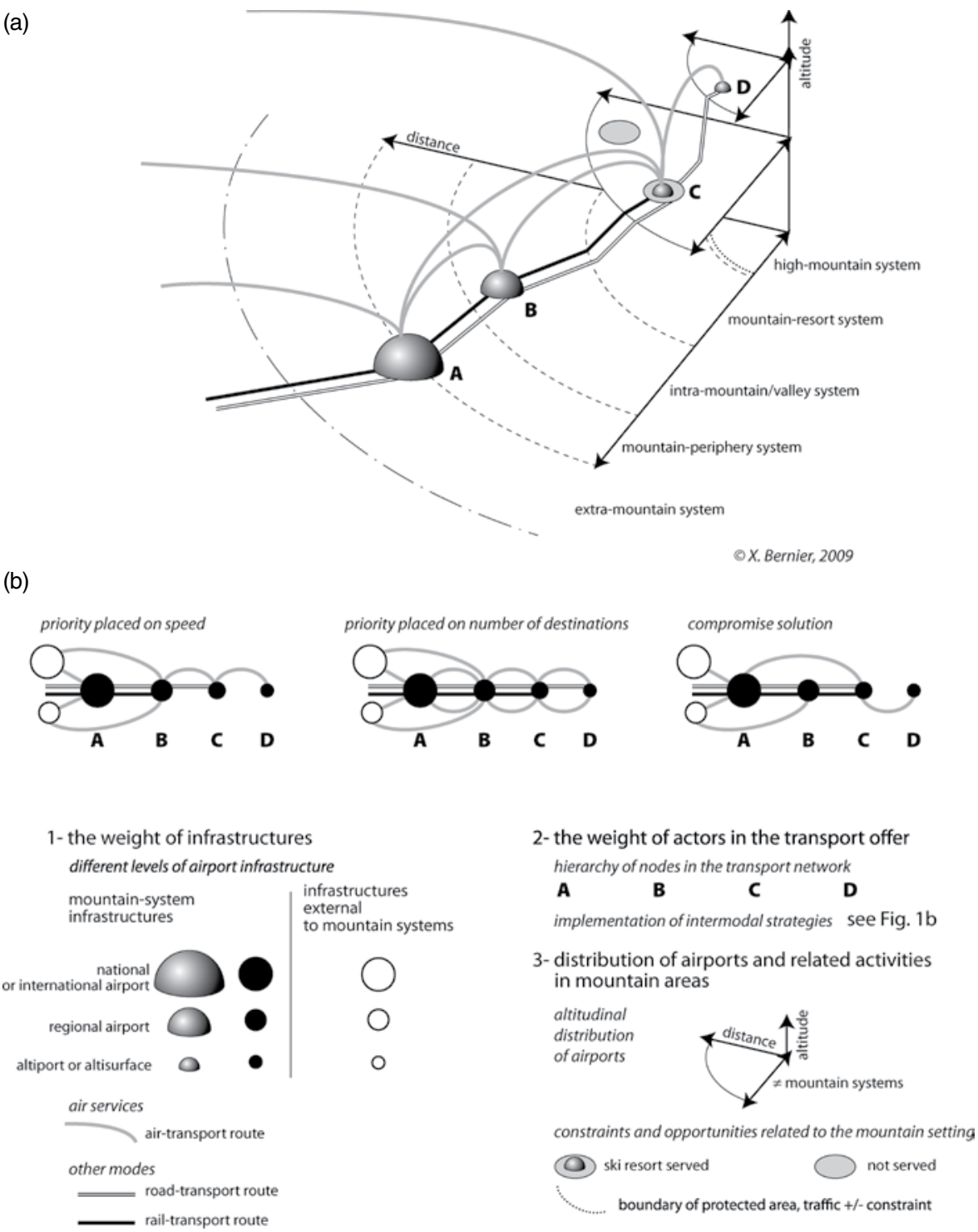

Figure 2: Intermodality and accessibility.

regional airports have been run by Vinci Airport and Keolis on behalf of the 'départemental' councils of Isère and Savoie. Passenger numbers have grown rapidly in recent years, increasing from 204,114 in 2004 to 469,777 in 2008 for Grenoble, and from 180,813 in 2004 to 270,632 in 2008 for Chambéry (source: Union des Aéroports Français). With 440,356 passengers between December 2008 and April 2009, Grenoble-St. Geoirs airport recorded a new record (257,592 passengers for ChambérySavoie for the same period). A detailed analysis of traffic flows provides much interesting information. First, it highlights the extremely seasonal character of passenger flows, thereby underlining the role these airports play in servicing the area's winter sports resorts. Chambéry airport has seen regular 
growth in charter traffic (snow charters), consisting of aircraft that are directly chartered by tour operators (British, Scandinavian and Russian) for package holidays (69\% of total traffic). The regular traffic is dominated by the British, through Flybe and Jet2, but no longer through Sterling Airlines since it went bankrupt. As pilots must have a special qualification to land and take off at Chambéry (special training that can be done on a simulator), most of the low-cost traffic (Easyjet, Ryanair, etc) has been absorbed by neighbouring Grenoble airport, which can also accommodate all types of aircraft. The British market is also very important at Grenoble airport, as British citizens account for $77 \%$ of passengers, thanks to regular flights to 11 United Kingdom airports (including three of London's airports: Stansted, Gatwick and Luton). Cross-channel charter traffic is also promoted by the presence of two of Europe's biggest tourism groups: Tui Travel and Thomas Cook. As a response to the growing competition from Geneva-Cointrin and Lyon-St. Exupéry airports, highly effective intermodal strategies have been developed. As well as direct TGV rail services to Grenoble, Chambéry and Bourg-St-Maurice, a wide range of road connections by coach are available. These coach services mostly provide connections to the main ski resorts (Altibus runs services from Chambéry airport to the resorts of the Tarentaise Valley, which include the largest ski area in the world), and to railway/coach stations: Grenoble railway station (service operated by Grenoble Altitude) and Lyon Part-Dieu (service operated by AG Bus). Hence, numerous intermodal combinations are possible and the connectivity index is high (at least during the winter), with a sometimes complex nodal structure [13].

\subsection{The case of 'on-demand' transport and business aviation}

Travellers whose most important consideration is time often make use of on-demand services, which are becoming increasingly personalised (Fig. 2). Traffic flows are small but, because they involve people who are likely to contribute heavily to the local economy, regional development bodies focus a lot of attention on this market. The air-service offer is complemented by luxury coach services run by different operators, chauffeur-driven limousines and taxis, etc. However, connections to final destinations are not the unique preserve of road transport, as several companies offer air-taxi and helicopter-taxi services from the regional airports. As a result, many valley-level airports have specific business-travel terminals. Designed to provide the fastest possible routes to the mountain resorts (type $\mathrm{C}$ airports), this type of service is provided by companies such as Helijet, based at Chambery airport, Air Zermatt, in the eponymous Swiss resort, and Air Glaciers, which provides fixed-wing and helicopter services from Sion airport (Switzerland). Traffic flows can be significant. For example, every winter 6,000 passengers arrive in Courchevel by air and a total of 15,000 air movements are recorded every year for the altiports at Alpe d'Huez, Megève and Méribel, although the latter figure includes other types of air movement, particularly pleasure flights around Mont-Blanc. This type of movement belongs to the category of sports and leisure aviation, and is of sufficient importance to have generated two pilots' associations (AFPM, French Association of Mountain Pilots and EMP European Mountain Pilots). This type of aerodrome also formed the starting point for heliskiing, an activity that is authorised in Switzerland but banned in France by the 'Loi Montagne' of 1985, which forbids the landing of skiers at altitudes above $1,500 \mathrm{~m}$ other than at altiports and helicopter landing grounds. When added to other restrictions related to protected areas, this has led to the development of services that take skiers to summits just outside France.

Once again, all these intermodal strategies are closely linked to tourism, with some cases concentrating on number of destinations served, some cases focusing on speed and others providing a compromise. 


\section{THE INTEGRATION OF REGIONAL AIRPORTS IN EVOLVING MOUNTAIN AND MOUNTAIN-PERIPHERY TRANSPORT SYSTEMS}

In all cases, these strategies have an impact on how well regional airports are integrated into the local/regional transport system (Fig. 3). The deregulation of air transport, particularly in Europe, has also contributed to a profound reorganisation of the field. One of the most important changes in air transport in recent years has been the development of low-cost airlines and services, which followed

(a)

(b)
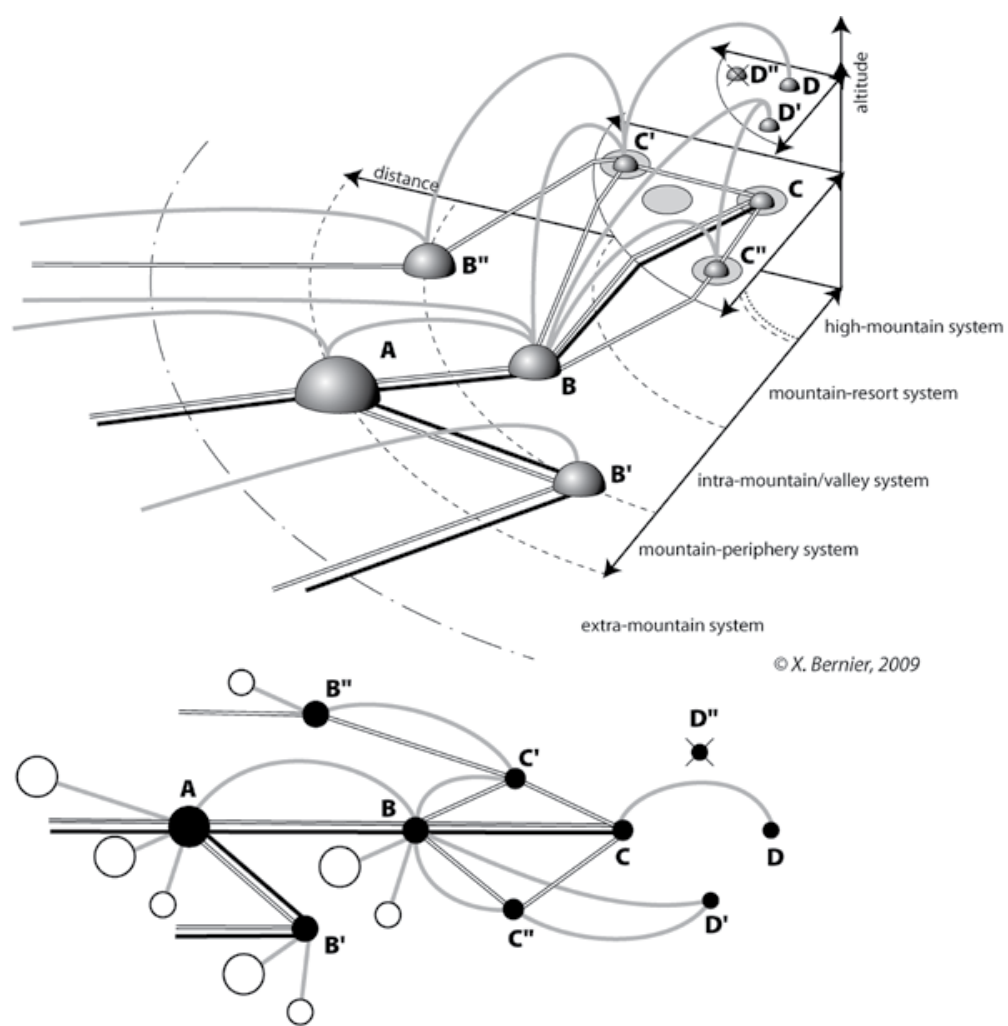

1- the weight of infrastructures

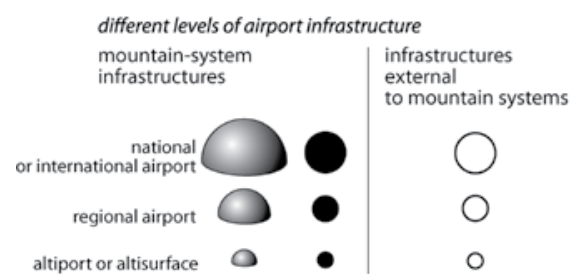

air-transport route

other modes

road-transport route rail-transport route 2-increasingly complex nodal morphologies

$$
\begin{aligned}
& \text { hierarchy of nodes in the transport network } \\
& \text { towards a reorganisation and a node-axis selection } \\
& \text { × runway closure see Fig. 3b }
\end{aligned}
$$

3- the role of regional airports

in the development of mountain areas

altitudinal distribution constraints and opportunities of airports related to the mountain setting

distance $\uparrow$ ski resort served

$\int_{\text {mountain }}{ }^{\text {not served }}$

boundary of protected area, traffic $+\%$ - constrain

B fully-integrated regional airport

B' regional airport with no links to the mountain system B regional airport with no links to the mountain system
B" regional airport specialised in certain types of traffic,

Figure 3: The place of regional airports in an evolving transport system. 
the liberalisation of the air-transport market. In addition, a hierarchy of accessibility and a polarisation around hubs have developed [12,14]. The current context is also one of increasingly fierce competition between different regional airports and between regional and national/international airports. Nevertheless, the effects have been most radical for secondary regional airports that offer only small numbers of direct services, and this has often led to uncertainty about the maintenance of these services. In addition, some temporary airstrips (on glaciers for example) are no longer used by commercial flights for legal reasons.

Changes to the accessibility of mountain areas are occurring very quickly; however, each type of airport is affected differently by these changes.

Type B regional airports include those that are completely integrated into local/regional transport systems. Type A mountain-periphery airports often fill this role because they offer maximum connectedness and connectivity for access to mountain areas, and because they are sometimes true multi-modal transport hubs. In the Western Alps, and for access to mountain areas, Geneva-Cointrin airport also tends to operate as a regional airport in competition with neighbouring French regional airports. At a lower level, but still in Switzerland, Zurich airport can also be considered a type B airport.

As well as being well integrated on an international and national level, Zurich airport has numerous air and land connections to mountain airports and resorts. It has excellent connections with railway (major CFF hub) and bus (13 regional bus routes and 600 daily bus services) stations.

Conversely, other mountain-periphery airports (type $\mathrm{B}^{\prime}$ ) do not have direct links with mountain areas. Tarbes-Lourdes-Pyrenees airport, at the foot of the French Pyrenees, undoubtedly falls into this category. It boasts substantial volumes of traffic and is one of France's largest airports in terms of passenger numbers. In 2008, the airport registered 678,897 passengers, an increase of $13.4 \%$ compared with 2004. Although it has three routes to Paris, $80 \%$ of its passengers are international, generally via charter flights, as there are no low-cost services. Most of the traffic is related to religious tourism and pilgrimages to Lourdes. Therefore, despite not having good intermodal connections, perhaps because of a lack of demand, the airport has very poor links to the true mountain system.

This is not the case of type $\mathrm{B}^{\prime \prime}$ airports, which include regional airports that specialise in specific types of traffic, often with limited or seasonal services. As explained above, most of the traffic through Grenoble and Chamberry airports is concentrated in the winter season, and most passengers are tourists from Northern Europe heading to the area's ski resorts. Many second-rank airports in the Himalayas, particularly in Nepal, also belong to this category. Built after the 1950s [15], these airports are part of a highly centralised network based around the capital Kathmandu. As a result, connectivity is quite low. Served by the national carrier (RNAC) or by a series of private airlines (such as Yeti Airlines), these airports, which include Pokhara, Bhaïrahawa, Biratnagar and Nepalgunj, can appear to be very rudimentary. In all cases, they are highly dependent on tourism.

\section{CONCLUSION}

The fragility of their business and a great dependence on tourism and on the global financial situation seem to be recurring characteristics of most regional airports linked to mountain areas. However, this tourism dependence can also be a strength, as tourists now play an essential role in determining the accessibility of mountain areas. This is true from the point of view of service provision, both in terms of direct services and in terms of the intermodal transport offer. The myth of airports as keys to development has frequently been nuanced or even highly criticised [16], on both regional and local scales. Although this myth is based on impetus effects (Chambéry airport is linked to Savoie Technolac technology park. Altiports can greatly affect a resort's real estate market), the greatest contribution of regional airports is in terms of an area's image. In their promotional strategies, and in order to ensure they have a high profile on the regional, national or even international stage, 
regional airports are an essential part of the development strategies implemented by mountain areas. However, for airports to contribute fully to an area's image in today's world, they must have the smallest possible impact on the environment.

\section{REFERENCES}

[1] Giblin, J.C., Les aéroports régionaux à la veille de la décentralisation. Hérodote - Aviation et géopolitique, 114(3), pp. 101-121, 2004.

[2] Union des aéroports français (eds), Résultats d'activité des aéroports français 2008, www. aeroports.fr, 59 p., 2009.

[3] Thompson, I.B., Air transport liberalisation and the development of third level airports in France. Journal of Transport Geography, 10(4), pp. 273-285, 2002. doi:10.1016/S0966-6923(02)00043-1

[4] Zembri, P., The spatial consequences of air transport deregulation: an overview of the French case since 1995, Nectar book, www.nectar-eu.org/, 30 p., 2005.

[5] Debarbieux, B., La montagne, un objet de recherche? Revue de Géographie Alpine, 89(2), 131 p., 2001.

[6] Sacareau, I., La montagne, une approche géographique, Belin Sup: Paris, 288 p., 2003.

[7] Haggett, P., L'analyse spatiale en Géographie Humaine, Armand Colin: Paris, 390 p., 1973.

[8] Abler, R., Adams, J. \& Gould, P., Spatial Organization: The Geographer's View of the World, Prentice Hall International: London, 587 p., 1972.

[9] Plassard, F., Les réseaux de transport et de communication (Chapter 28). Encyclopédie de Géographie, Economica: Paris, pp. 533-556, 1992.

[10] Pumain, D. \& St-Julien, Th., L'analyse spatiale - Localisation dans l'espace, Armand Colin: Paris, 167 p., 2004.

[11] Chapelon, L. \& Bozani, S., L'intermodalité air-fer en France: une méthode d'analyse spatiale et temporelle. L'Espace Géographique, 1, pp. 60-76, 2003.

[12] Kelly, O. \& Morton, E., A geographer's analysis of hub-and-spokes networks. Journal of Transport Geography, 6(3), pp. 171-186, 1998. doi:10.1016/S0966-6923(98)00010-6

[13] Bernier, X., Transports et montagne: quelle spécificité pour les sytèmes nodaux? Proposition d'un modèle synthétique illustré à travers l'itinéraire transalpin Grenoble-Bourg d'OisansBriançon-Suse. Cahiers Scientifiques des Transports, 48, pp. 81-97, 2005.

[14] Bavoux, J.J., Beaucire, F., Chapelon, L. \& Zembri, P., Géographie des transports, Armand Colin: Paris, 232 p., 2005.

[15] Bernier, X., Transports, communications et développement en Himalaya central: le cas du Népal, PhD, Univ-Aix-en-Provence France, 443 p., 1996.

[16] Offner, J.M., Les effets structurants du transport: mythe politique, mystification scientifique. L'Espace Géographique, 3, pp. 233-242, 1993. 